\title{
Efficient Medium for Protease Production by Bacillus licheniformis MZK05M9 Optimized through Response Surface Methodology
}

\author{
Md. Mahmuduzzaman Mian ${ }^{a}$, Md. Arafat Al Mamun ${ }^{b}$, Shakila Nargis Khan ${ }^{a}$, Md. Mozammel Hoq ${ }^{*}$
}

\begin{abstract}
Background. Due to certain limitations, the bioprocess development for protease production needs more convenient and realistic statistical approach instead of conventional optimization technique. For an economic bioprocess with enhanced protease yield, Response Surface Methodology (RSM) based on Central Composite Design (CCD) was employed and evaluated in this study. Materials and methods. The fermentation was performed with a mutant strain, Bacillus licheniformis MZK05M9 (BIM9) using molasses, urea and $\mathrm{CaCl}_{2} \cdot 2 \mathrm{H}_{2} \mathrm{O}$ as carbon, nitrogen and trace element sources respectively in shake flask. The conditions for fermentation were maintained with temperature, $\mathrm{pH}$ and agitation at $37^{\circ} \mathrm{C}, 7.5$ and $150 \mathrm{rpm}$ respectively. The required number of trials were determined by investigating each variable (Molasses, Urea and $\mathrm{CaCl}_{2}$ ) at five levels: - $\mathrm{a},-1$, $0,+1$ and $+a$ through CCD with protease yield as the response function and the interaction effects as well as optimal parameters were obtained by using Minitab software. The significance of the independent variables and their interactions were tested by means of analysis of variance (ANOVA) with a $95 \%$ confidence level and 3-D surface plots were developed through RSM. Results. Upon 20 trials, the optimum values of the
\end{abstract}

\section{Significance | Economic production of protease by statistical approach.}

*Correspondence: Md. Mozammel Hoq, Professor, Department of Microbiology, University of Dhaka, Dhaka-1000, Bangladesh. Tel: 9661920-73/7734, +8801717083673,

E-mail: mhoq@du.ac.bd

Edited by Samiran Bhattacharjee, PhD, CARS, University of Dhaka, Dhaka-1000, Bangladesh., and accepted by the Editorial Board July 25, 2018 (received for review March 4, 2018) tested variables for maximum alkaline protease production as predicted through CCD and RSM were as $0.63 \%$, $0.16 \%$, and $0.11 \%(\mathrm{w} / \mathrm{v})$ for Molasses, Urea and $\mathrm{CaCl}_{2} \cdot 2 \mathrm{H}_{2} \mathrm{O}$, respectively. The protease activity in Conventionally Optimized (CO) medium was $410 \mathrm{U} / \mathrm{ml}$ and it was predicted as $463.1 \mathrm{U} / \mathrm{ml}$ for statistically optimized medium. Upon experiments with the optimized medium, the protease activity was estimated as $560 \mathrm{U} / \mathrm{ml}$ which was $36.6 \%$ (i.e. 1.36 fold) higher than that of $\mathrm{CO}$ medium. Conclusion. The efficiency of the enzyme in solubilizing the whole feathers was also assessed which indicated that the enzyme produced with cheap substrates could be utilized as a cost effective and eco-friendly agent in poultry feed formulation, leather processing etc.

Keywords: Bacillus licheniformis MZK05M9, Central Composite Design (CCD), Response Surface Methodology (RSM), Protease, Economic bioprocess.

Abbreviations: RSM, Response Surface Methodology; CCD, Central Composite Design; ANOVA, Analysis of Variance; TCA, Trichloroacetic acid; BSA, Bovine Serum Albumin; rpm, Rotation per minute; BlM9, Bacillus licheniformis MZK05M9.

\section{Introduction}

Proteases are proteolytic enzymes with the ability to degrade protein by breaking down the hydrogen bonds that bind and keep peptides together into specific foldings. Proteases are vital in terms of their physiological roles and commercial applications

\footnotetext{
Author Affiliation:

a Department of Microbiology, University of Dhaka, Dhaka-1000, Bangladesh.

${ }^{\mathrm{b}}$ Centre for Advanced Research in Sciences, University of Dhaka, Dhaka-1000

Please cite this article:

Mian MM, Mamun Md Arafat Al, Khan Shakila Nargis, Hoq MM (2018). Efficient Medium for Protease Production by Bacillus licheniformis MZK05M9 Optimized through Response Surface Methodology. Microbial Bioactives, 1(1), 022-028.
} 
and a wide range of microorganisms including bacteria, moulds, yeasts and actinomycetes etc produce this enzyme (Akcan \& Uyar, 2011). Among bacteria, Bacillus licheniformis, B. subtilis, B. horikoshii, B. sphaericus, B. furmis, B. alcalophilus (Adinarayana, Bapi Raju, \& Ellaiah, 2004) are considered as the attractive producer of proteases for their industrial feasibility. Bangladesh being one of the leading exporter of leather and textile products, needs to take the advantages of protease very badly to ameliorate the current environment pollution as well as the product quality. At present, protease is commercially being produced by fermentation technology in Bangladesh with a mutant strain, Bacillus licheniformis MZK05M9 (BlM9) which exhibited about three fold higher enzyme activity than that of the wild one (Hoq, Siddiquee, Kawasaki, \& Seki, 2005; Salaheen, Mamun, Khan, \& Hoq, 2015) and kerA gene was also cloned in E. coli BL-2 1 by recombinant DNA technology for higher yield and feasible downstream processing (Nahar et al., 2016).

In fermentation biotechnology, enzyme productivity is increased by optimizing the media ingredients and improving the strains by mutation or gene cloning (Davati \& Najafi, 2013). In order to optimize medium, conventional 'one factor at a time' technique was in vogue which is a laborious, expensive and lengthy process unable to provide a comprehensive view of the system behaviour ignoring the effects of all parameters involved with baffling results and lack of predictability (Gokhale, Patil, \& Bastawde, 1991). To avoid such problems, Response Surface Methodology (RSM) has been employed with a series of statistical and mathematical techniques to design an efficient medium (Hajji, Rebai, Gharsallah, \& Nasri, 2008; Lakshmi \& Hemalatha, 2015, 2016; Saxena \& Singh, 2010). RSM is a statistical tool in multivariate systems which fits the studied experimental domain in the theoretical design through a response function (Nazir, Shuib, Kalil, Song, \& Hamid, 2018; Sarrai et al., 2016; C. Song, Li, Wang, \& Shi, 2016) and is useful for constructing models in which a response of interest being influenced by selected variables with the objective of representing optimal values (Deepak et al., 2008; Liu \& Wang, 2007; Montgomery, 2006; Sayyad, Panda, Javed, \& Ali, 2007). For more accurate and true response surface, a wide variety of functional forms of second-order models, e.g. Central Composite, Box-Behnken and Doehlert designs, are employed (Adinarayana \& Ellaiah, 2002; Carvalho, Serralheiro, Cabral, \& Aires-Barros, 1997; Li et al., 2007; Rahman \& Gomes, 2003; Srinivas, Chand, \& Lonsane, 1994; Xiao, Liu, Qin, \& Xu, 2007). Optimization of several bioprocesses, including fermentations (Sen, 1997) and enzyme immobilization techniques (Chang, Chang, Yen, \& Shieh, 2007; Z. Song et al., 2007) etc. involve RSM and experimental designs to save cost and time along with improved productivity and reduced process variability (Rao, Kim, \& Rhee, 2000).

The alkaline protease production potential of the mutant strain
BlM9 in commercial media and various cheap substrate especially soybean meal based media was investigated employing RSM and CCD (Mamun, Mian, Saifuddin, Khan, \& Hoq, 2017). With a view to avoiding probable complexities during downstream processing of enzyme due to soybean meal and developing a more cost effective bioprocess, molasses, urea and $\mathrm{CaCl}_{2}$ based medium was proposed and optimized involving RSM and CCD. Whether the optimized medium obtained through statistical approach supports better enzyme productivity or not was also evaluated in this study.

\section{Materials and methods}

Bacterial strain. A mutant bacterial strain Bacillus licheniformis MZK05M9 (BlM9) obtained from the Enzyme and Fermentation Biotechnology Laboratory, Department of Microbiology, University of Dhaka, was used in this study.

Inoculum preparation. $5 \mathrm{ml}$ of Tryptone Soy Broth (TSB) medium (Sigma, USA) [pH 7.5] prepared in a test tube was autoclaved and 1 single colony of BlM9 mutant strain from Tryptone Soy Agar was inoculated aseptically in that medium. Upon overnight incubation at $37^{\circ} \mathrm{C}$, fresh bacterial culture was used everytime as inoculum in further fermentation process.

Medium optimization through statistical approach. The amounts (\%) of Molasses, Urea (Merck, Germany) and $\mathrm{CaCl}_{2} \cdot \mathrm{H}_{2} \mathrm{O}$ (Sigma, USA) required for maximum enzyme yield were optimized through the statistical program Response Surface Methodology (RSM). A Central Composite Design (CCD) with three independent variables i.e. Molasses, Urea and $\mathrm{CaCl}_{2} \cdot \mathrm{H}_{2} \mathrm{O}$ was applied to determine the required number of trials and the amounts of variables through the factorial design.

A total of 20 experiments was found to be sufficient to calculate the coefficients of the second-order polynomial regression model for the three variables. Each variable was investigated at five levels, i.e. $-\alpha,-1,0,+1$ and $+\alpha$, as shown in Table 1 where the highest and lowest values of the variables were considered from the previous reports (Abinaya, Ramya, Sivakami, Ponnusami, \& Sugumaran, 2017; Huang, Badger, Haney, \& Evans, 2007; Qureshi, Bhutto, Khushk, \& Dahot, 2011; Suganthi et al., 2013). The enzyme yield is thus explained by the following empirical second order polynomial model.

$Y=\beta_{0}+\beta_{1} X_{1}+\beta_{2} X_{2}+\beta_{3} X_{3}+\beta_{11} X_{1}^{2}+\beta_{22} X_{2}^{2}+\beta_{33} X_{3}^{2}+\beta_{12} X_{1} X_{2}+\beta_{13} X_{1} X_{3}+\beta_{23} X_{2} X_{3} \ldots \ldots \ldots$ (1)

Here, $\mathrm{Y}$ is the enzyme yield, $\beta_{0}$ is the interception coefficient, $\beta_{1}$, $\beta_{2}$ and $\beta_{3}$ are linear coefficients; $\beta_{11}, \beta_{22}$ and $\beta_{33}$ are quadratic terms; $\beta_{12}, \beta_{13}$ and $\beta_{23}$ are interaction coefficients and $X_{1}, X_{2}$ and $X_{3}$ are coded independent variables studied.

The analyses were carried out in triplicate and the statistical analysis was performed using the Minitab software (Version 17). Data were analyzed by the analysis of variance (ANOVA), and p-value lower then 0.05 was considered significant in surface response analysis. The optimal values of the operation parameters 
Table 1 | Level of independent variables established according to central composite design (CCD).

\begin{tabular}{llllll}
\hline Independent variables & High (+1) & Low (-1) & Mean $(\mathbf{0})$ & $+\boldsymbol{\alpha}$ & $-\boldsymbol{\alpha}$ \\
\hline Molasses & 1 & 0.5 & 0.75 & 1.17 & 0.33 \\
Urea & 0.2 & 0.1 & 0.15 & 0.234 & 0.066 \\
$\mathrm{CaCl}_{2} .2 \mathrm{H}_{2} \mathbf{O}$ & 0.1 & 0.05 & 0.075 & 0.117 & 0.033
\end{tabular}

Table 2 | Experimental designs of the five levels and the respective experimental results as well as predictive values. ${ }^{\star} E A$ : Enzyme activity which indicates the enzyme yield. Trials Molasses Urea $\mathrm{CaCl}_{2} 2 \mathrm{H}_{2} \mathrm{O}$ Experimental Predicted Residuals ${ }^{*} \mathrm{EA}(\mathrm{U} / \mathrm{ml}) \quad \mathrm{EA}(\mathrm{U} / \mathrm{ml})$

\begin{tabular}{lllllll}
\hline $\mathbf{1}$ & 0.5 & 0.1 & 0.05 & 320 & 333.035 & -13.0352 \\
$\mathbf{2}$ & 1 & 0.1 & 0.05 & 397 & 398.268 & -1.2678 \\
$\mathbf{3}$ & 0.5 & 0.2 & 0.05 & 450 & 432.516 & 17.4837 \\
$\mathbf{4}$ & 1 & 0.2 & 0.05 & 420 & 440.749 & -20.7489 \\
$\mathbf{5}$ & 0.5 & 0.1 & 0.1 & 430 & 410.042 & 19.9580 \\
$\mathbf{6}$ & $\mathbf{1}$ & 0.1 & 0.1 & 402 & 420.275 & -18.2746 \\
$\mathbf{7}$ & 0.5 & 0.2 & 0.1 & 455 & 454.523 & 0.4769 \\
$\mathbf{8}$ & 1 & 0.2 & 0.1 & 420 & 407.756 & 12.2443 \\
$\mathbf{9}$ & 0.33 & 0.15 & 0.075 & 360 & 375.177 & -15.1771 \\
$\mathbf{1 0}$ & 1.17 & 0.15 & 0.075 & 407 & 390.704 & 16.2956 \\
$\mathbf{1 1}$ & 0.75 & 0.066 & 0.075 & 390 & 382.878 & 7.1224 \\
$\mathbf{1 2}$ & 0.75 & 0.234 & 0.075 & 450 & 456.004 & -6.0039 \\
$\mathbf{1 3}$ & 0.75 & 0.15 & 0.033 & 432 & 421.935 & 10.0647 \\
$\mathbf{1 4}$ & 0.75 & 0.15 & 0.117 & 450 & 458.946 & -8.9462 \\
$\mathbf{1 5}$ & 0.75 & 0.15 & 0.075 & 458 & 449.365 & 8.6347 \\
$\mathbf{1 6}$ & 0.75 & 0.15 & 0.075 & 454 & 449.365 & 4.6347 \\
$\mathbf{1 7}$ & 0.75 & 0.15 & 0.075 & 444 & 449.365 & -5.3653 \\
\hline & & & & & & \\
\hline
\end{tabular}

estimated by the three-dimensional response surface analysis of the independent variables (Molasses, Urea and $\mathrm{CaCl}_{2} \cdot \mathrm{H} 2 \mathrm{O}$ ), the range and levels of which are mentioned in Table 1 , and the dependent variable (Y).

Production of Alkaline Protease in shake Flask. The amount (\%) of molasses, urea and $\mathrm{CaCl}_{2}$ for the trials was determined by the factorial design for variable optimization as specified in Table 2. These varying amounts of ingredients were used accordingly to prepare the media of different compositions for protease production in $500 \mathrm{~mL}$ Erlenmeyer flask and the $\mathrm{pH}$ was maintained at 7.5. The media upon sterilization were inoculated with the mutant, BlM9 and in all cases, the required amount of inoculum was standardized so that the incubation starts at an OD600nm of 0.1 . The flasks were then kept in an orbital shaking incubator (New Brunswick ${ }^{\mathrm{ma}}$ Excella $^{\oplus}$ E25, USA) at $37^{\circ} \mathrm{C}$ and 150 rpm.

Protease assay. Protease activity was determined according to the modified method of Kreger and Lockwood (Mamun et al., 2017). In brief, $400 u$ of $1 \%$ Azo-casein (Sigma, USA) solution in 0.05 M Tris -HCI buffer [pH 8.5] (Sigma, USA) was mixed with 400ul of culture supernatant and kept for 1 hour at $37^{\circ} \mathrm{C}$. The reaction was then stopped by adding $135 \mathrm{ul}$ of $35 \%$ trichloroacetic acid (TCA) (BDH, England) and the mixture was kept at $4^{\circ} \mathrm{C}$ for 2- $3 \mathrm{~min}$. Upon centrifugation at 13,000 rpm for $10 \mathrm{~min}, 0.75 \mathrm{ml}$ of the supernatant was mixed with $0.75 \mathrm{ml}$ of $1.0 \mathrm{M} \mathrm{NaOH}$ (Merck, Germany) and the absorbances taken at $440 \mathrm{~nm}$ were recorded immediately against the control, prepared initially by adding TCA into the culture supernatant to inhibit the enzyme activity. One unit of protease activity was considered as the amount of enzyme that produces an increase of 0.01 in absorbance under the above assay conditions.

Estimation of extra cellular protein concentration. The extracellular soluble protein in the culture supernatant was estimated following Bradford method and using Bovine Serum Albumin (BSA) (Sigma, USA) as a standard (Ernst \& Zor, 2010).

\section{Results and Discussion}

Medium ingredients for protease production. With a view to economic production of protease by mutant BlM9, molasses, a byproduct of sugar industry, and urea were chosen as carbon and nitrogen source respectively. Molasses has successful history of use as an inexpensive sole carbon source for the production of many microbial enzymes (El-Enshasy, Mohamed, Farid, \& El-Diwany, 2008; Helal, Amer, \& Abdelwahed, 2012; Mourin, Shishir, Khan, \& Hoq, 2015; Qureshi et al., 2011) and urea was reported to provide excellent support as nitrogen source in many cases (Abinaya et al., 2017; Aksoy, Uzel, \& Hameş Kocabaş, 2012; Huang et al., 2007; Suganthi et al., 2013). On the other hand, divalent metal ions are required in the fermentation medium for optimum production of alkaline protease, protection of enzymes from conformational changes and to regulate the enzyme activity positively. Calcium derivative i.e. $\mathrm{CaCl}_{2}$, for such roles and inducing as well as stabilizing capacities for many enzymes (Bhunia, Basak, \& Dey, 2012; Sharma, Kumar, Panwar, \& Kumar, 2017) was chosen as mineral source. The selection of cheap substrates could thereby result in a reduction of approximately $30 \%$ in the production cost of protease enzyme as compared to other previous studies (Hoq et al., 2013; Mamun et al., 2017; Md. Mahmuduzzaman Mian, 2014).

Optimization of the amount of ingredients for maximum protease yield is a prerequisite in bioprocess development for which a statistical approach, Response Surface Methodology was employed instead of conventional one variable at a time technique which usually fails to consider the effects of all the parameters involved. RSM is a combination of statistical and mathematical methods to select the best experimental conditions employing the lowest number of experiments in order to get appropriate results (Arslan-Alaton, Tureli, \& Olmez-Hanci, 2009; Sarrai et al., 2016). RSM Model Development

The effects of three variables including Molasses, Urea and $\mathrm{CaCl}_{2} \cdot 2 \mathrm{H}_{2} \mathrm{O}$ on the protease enzyme production were selected as 
Table 3 | ANOVA for the response surface quadratic model. $R^{2}=0.8879$, Adjusted $R^{2}=0.7870$

\begin{tabular}{|c|c|c|c|c|c|c|c|}
\hline Source & Df & Seq SS & Contribution & $\begin{array}{l}\text { Adjusted } \\
\text { ss }\end{array}$ & $\begin{array}{l}\text { Adjusted } \\
\text { MS }\end{array}$ & $\begin{array}{l}\text { F } \\
\text { value }\end{array}$ & $\begin{array}{l}p \text { - } \\
\text { value }\end{array}$ \\
\hline Model & 9 & 21987.5 & $88.79 \%$ & 21987.5 & 2443.05 & 8.80 & 0.001 \\
\hline Linear & 3 & 8399.5 & $33.92 \%$ & 8399.5 & 2799.83 & 10.09 & 0.002 \\
\hline A & 1 & 291.0 & $1.18 \%$ & 291.0 & 291.03 & 1.05 & 0.330 \\
\hline B & 1 & 6454.9 & $26.07 \%$ & 6454.93 & 6454.93 & 23.26 & 0.001 \\
\hline C & 1 & 1653.5 & $6.68 \%$ & 1653.5 & 1653.51 & 5.96 & 0.035 \\
\hline Square & 3 & 8938.5 & $36.10 \%$ & 8938.5 & 2979.49 & 10.74 & 0.002 \\
\hline$A^{*} A$ & 1 & 7260.9 & $29.32 \%$ & 7948.2 & 7948.23 & 28.64 & 0.000 \\
\hline$B * B$ & 1 & 1534.1 & $6.20 \%$ & 1613.1 & 1613.13 & 5.81 & 0.037 \\
\hline $\mathrm{C}^{\star} \mathrm{C}$ & 1 & 143.5 & $0.58 \%$ & 143.5 & 143.48 & 0.52 & 0.489 \\
\hline 2 way interaction & 3 & 4639.5 & $18.78 \%$ & 4649.5 & 1549.83 & 5.58 & 0.016 \\
\hline$A^{*} B$ & 1 & 1624.5 & $6.56 \%$ & 1624.5 & 1624.50 & 5.85 & 0.036 \\
\hline $\mathbf{A}^{*} \mathrm{C}$ & 1 & 1512.5 & $6.11 \%$ & 1512.5 & 1512.50 & 5.45 & 0.042 \\
\hline $\mathrm{B}^{* \mathrm{C}}$ & 1 & 1512.5 & $6.11 \%$ & 1512.5 & 1512.50 & 5.45 & 0.042 \\
\hline Error & 10 & 2775.5 & $11.21 \%$ & 2775.5 & 277.55 & & \\
\hline Lack of Fit & 5 & 2554.2 & $10.31 \%$ & 2554.2 & 510.83 & 11.54 & 0.009 \\
\hline Pure Error & 5 & 221.3 & $0.89 \%$ & 221.3 & 44.27 & & \\
\hline Total & 19 & 24763.0 & $100.0 \%$ & & & & \\
\hline
\end{tabular}

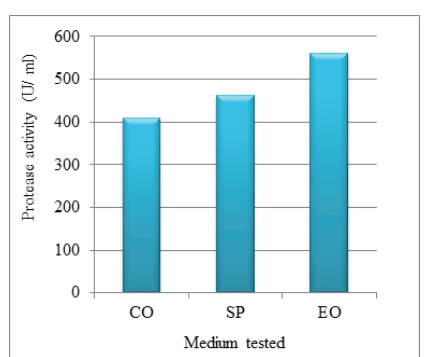

Figure 2 | Comparison of protease yields among the media in shake flask culture. (CO: Conventionally optimized, SP: Software predicted and EO: Experimentally obtained).
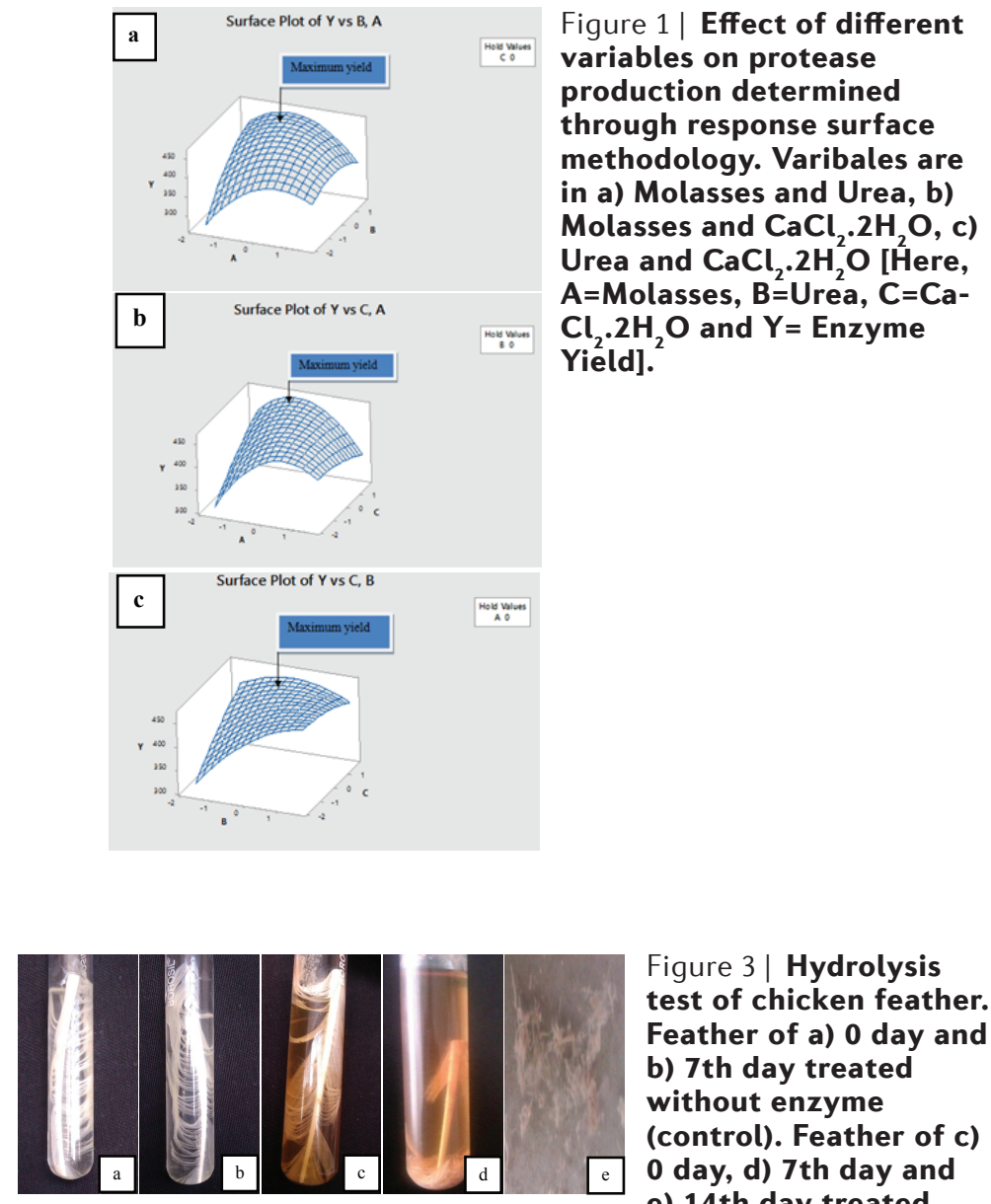

Figure 3| Hydrolysis test of chicken feather. Feather of a) 0 day and b) 7 th day treated without enzyme (control). Feather of $c$ ) 0 day, d) 7 th day and e) 14th day treated with the enzyme. factors in the Central Composite Design. As a response, the protease enzyme activity was chosen and a total of 20 experiments were employed for the response surface modeling (Table 2) where the order of experiments was arranged randomly. The observed and predicted results for the enzyme activity are also recorded in Table 2. The coefficients of the second-order fitting equation was to calculated using Minitab software (Version 17) and the ANOVA test was employed to assess the suitability of the models. Thus the second-order polynomial equation could be expressed by Equation (2) (conf. Equation (1)):

Protease Yield, $\mathrm{Y}=449.37+4.62 \mathrm{X}_{1}+21.74 \mathrm{X}_{2}+11.00 \mathrm{X}_{3}-23.48 \mathrm{X}_{1}{ }^{*} \mathrm{X}_{1}-10.58 \mathrm{X}_{2}{ }^{*} \mathrm{X}_{2}-3.16 \mathrm{X}_{3}{ }^{*} \mathrm{X}_{3}$ - $14.25 \mathrm{X}_{1}{ }^{*} \mathrm{X}_{2}-13.75 \mathrm{X}_{1}{ }^{*} \mathrm{X}_{3}-13.75 \mathrm{X}_{2}^{*} \mathrm{X}_{3} \ldots \ldots \ldots \ldots \ldots$ (2)

Where $\mathrm{X}_{1}$ is Molasses, $\mathrm{X}_{2}$ is Urea and $\mathrm{X}_{3}$ is $\mathrm{CaCl}_{2} \cdot 2 \mathrm{H}_{2} \mathrm{O}$.

According to the monomial coefficient value of regression model Equation (2), $\mathrm{X}_{1}=4.62$ (Molasses), $\mathrm{X}_{2}=21.74$ (Urea) and $\mathrm{X}_{3}=$ $11.00\left(\mathrm{CaCl}_{2} .2 \mathrm{H}_{2} \mathrm{O}\right)$, and the order of priority among the main effect of impact factors is Molasses $(\mathrm{X} 1)>\mathrm{CaCl}_{2} \cdot 2 \mathrm{H}_{2} \mathrm{O}\left(\mathrm{X}_{3}\right)>$ Urea $\left(\mathrm{X}_{2}\right)$.

\section{Statistical Analysis}

The results of the analysis of variance (ANOVA) as summarized (Table 3), implies the soundness of the model. ANOVA subdivides the total variation in a set of data into component parts associated with specific sources of variation in order to test the hypotheses on the parameters of the model (Sarrai et al., 2016). The statistical significance in all analyses was determined at a $95 \%$ confidence level $(\alpha=0.05)$. Various descriptive statistics such as the p-value, F-value, and the degree of freedom (df) were used to assess the results; the determination coefficient $\left(R^{2}\right)$ of each coefficient in Equation (2) was determined by Fisher's F-test and values of probability $>$ F. As shown in Table 3 , a small probability value ( $\mathrm{p}$ $<0.001$ ) indicates that the model was highly significant and could be used to predict the response function accurately. The coefficients of determination $\mathrm{R}^{2}$ (correlation coefficient) and adjusted coefficients of determination $\mathrm{R}^{2}$ adj were used to evaluate the Goodness-of-fit for the model. The larger the value of the correlation coefficient, the higher the reliability of the model in predicting the response. Here in this study, the $\mathrm{R}^{2}=0.8879$ indicated that $88.79 \%$ of the response variability could be explained by the model for the protease enzyme yield as a response.

\section{Effects of model parameters and their interactions}

The significance of each model parameter was determined by means of Fischer's F- value and p-value. The F-value is the test for comparing the curvature variance with residual variance and probability $>\mathrm{F}$ (p-value) is the probability of seeing the observed F- value if the null hypothesis is true. Since small probability values call for rejection of the null hypothesis and the curvature is 
not significant, the larger the F- value and the smaller the $\mathrm{p}$ value, the more significant the corresponding coefficient is (Bayraktar, 2001). It was concluded that one of the independent variables of the quadratic model, urea is highly significant parameters as $\mathrm{p}<0.001$ (Table 3). Moreover, linear terms of $\mathrm{CaCl}_{2} \cdot 2 \mathrm{H}_{2} \mathrm{O}$ and the square effects, $\mathrm{A}^{\star} \mathrm{A}, \mathrm{B}^{\star} \mathrm{B}$ and the combination of $A^{\star} B, A^{\star} C, B^{\star} C$ are significant because $\mathrm{p}<0.05$ (Table 3). Likewise the linear terms of $A$ and the square effects of $C^{\star} C$ are insignificant (Where $\mathrm{A}=$ Molasses, $\mathrm{B}=$ Urea and $\mathrm{C}=\mathrm{CaCl}_{2} \cdot 2 \mathrm{H}_{2} \mathrm{O}$ ).

The Minitab software was used to genrate three-dimensional (3D) response surfaces which are graphical representations of the regression equation for the optimization of amounts of medium ingredients for maximum protease yield. In these plots, the response functions of two factors are presented while all other factors are at the fixed levels. The results of the interactions between three independent variables and the dependent variable are shown in Figure 1.

The individual and mutual effects of Molasses and Urea on the protease yield as depicted in the surface plot (Figure 1) revealed that the highest yield was attained when Urea level was high and Molasses level was low. Again in Figure 1b, the individual and mutual effects of Molasses and $\mathrm{CaCl}_{2} .2 \mathrm{H} 2 \mathrm{O}$ on the protease yield as shown by the surface plot indicates that the highest yield was obtained when $\mathrm{CaCl}_{2} \cdot 2 \mathrm{H}_{2} \mathrm{O}$ level was high and Molasses level was low. Similarly, Figure 1c shows the individual and mutual effects of Urea and $\mathrm{CaCl}_{2} \cdot 2 \mathrm{H}_{2} \mathrm{O}$ on the protease yield. The relevant surface plot demonstrates that the highest yield is obtained when both Urea and $\mathrm{CaCl}_{2} \cdot 2 \mathrm{H}_{2} \mathrm{O}$ levels are high but $\mathrm{CaCl}_{2} \cdot 2 \mathrm{H}_{2} \mathrm{O}$ has greater effect than that of Urea. Finally it could be concluded that, molasses, urea and $\mathrm{CaCl}_{2} \cdot 2 \mathrm{H}_{2} \mathrm{O}$ had a positive effect on protease yield.

\section{Evaluation of the software optimized medium}

The maximum enzyme activity i.e. the enzyme yield as predicted by the software Minitab for the optimized medium was $463.1 \mathrm{U} /$ $\mathrm{ml}$ and the composition i.e. Molasses- $0.6353 \%$, Urea- $0.1627 \%$ and $\mathrm{CaCl}_{2} \cdot 2 \mathrm{H}_{2} \mathrm{O}-0.1170 \%$ for the respective medium was optimized by regression model. The efficiency of the optimized medium was assessed in shake flask fermentation following protease production by the strain BlM9 and the protease yield was estimated as $560 \mathrm{U} / \mathrm{ml}$ (Figure 2). It could be observed that the protease yield was increased to 1.3 fold than that $(410 \mathrm{U} / \mathrm{ml})$ of conventionally optimized medium.

Protease yields were improved through such statistical approaches as reported previously e.g. 14.0 fold increase (final activity $770.66 \mathrm{U} / \mathrm{mL}$ ) by Aspergillus clavatus ES1 through RSM \& Plackett-Burman design (Hajji et al., 2008), 1.4 fold increase (final $185.4 \mathrm{U} / \mathrm{mL}$ ) in basal medium by Bacillus licheniformis through RSM \& CCD (Lakshmi \& Hemalatha, 2016), 1.24 fold increase (final $205 \pm 0.35 \mathrm{U} / \mathrm{mL}$ ) in basal medium Bacillus cereus strain S8 through RSM \& CCD (Lakshmi \& Hemalatha, 2015) and 1.75 fold increase (final $577 \mathrm{U} / \mathrm{mL}$ ) in glucose-soybean medium by Bacillus sp. through RSM \& CCD (Saxena \& Singh, 2010). Interestingly, although the medium optimized in this study is composed of very cheap substrates, it demonstrated highly comparable protease yield.

Beside azo-casein digest method, protease activity of culture supernatant was further evaluated by feather digest method in test tubes in parallel to control i.e. uninoculated broth. Degradation of feather was not observed in control case up to 14 days whereas after 7 days, feather was completely digested by the culture supernatant containing the secreted extracellular protease (Figure 3 ). Upon $60 \%$ ammonium sulfate precipitation, the crude enzyme was concentrated and a 3.025 fold increase in specific activity was obtained. Further ultrafiltration by centricon-100 (Roti spin, Carl Roth, Germany) caused an increase of 16.59 folds in specific activity (Data not shown) which suggested about an effective mean for downstream processing i.e. purification of the enzyme through cross flow velocity ultrafiltration would be a correct choice.

\section{Conclusion}

The enzyme yield was improved by involving the statistical approach, RSM \& CCD, instead of conventional method and previous studies also recommended this upgradation in bioprocess technology. Molasses, Urea and $\mathrm{CaCl}_{2}$ based medium thus optimized would be economic reducing the costs both in upstream and downstream processing which in turn, will facilitate industrial production and application of proteases in Bangladesh.

\section{Author contributions}

MMM designed the research, performed the experiments and drafted the manuscript. AAM supervised the experiments and evaluated the data as well as results of the manuscript meticulously. SNK and MMH supervised the whole research and reviewed the manuscript critically.

\section{Acknowledgment}

The authors would like to thank Mohammad Saifuddin and Md. Arafat Rahman for their supports in statistical design.

\section{Competing financial interests}

Authors have declared that no competing interest exist.

\section{References}

Abinaya, R., Ramya, P., Sivakami, V., Ponnusami, V., \& Sugumaran, K. R. (2017). Alkaline protease production by Bacillus sp. MTCC 511 from cost effective substrate. Journal of Chemical and Pharmaceutical Sciences, 10(1), 488-491.

Adinarayana, K., Bapi Raju, K. V. V. S. ., \& Ellaiah, P. (2004). Investigations on alkaline 
protease production with $\mathrm{B}$. subtilis PE-11 immobilized in calcium alginate gel beads. Process Biochemistry, 39(11), 1331-1339. https://doi.org/10.1016/S0032-9592(03)00263-2

Adinarayana, K., \& Ellaiah, P. (2002). Response surface optimization of the critical medium components for the production of alkaline protease by a newly isolated Bacillus sp. Journal of Pharmacy \& Pharmaceutical Sciences, 5(3), 272-8. Retrieved from http://www.ncbi.nlm.nih.gov/pubmed/12553896

Akcan, N., \& Uyar, F. (2011). Production of extracellular alkaline protease from Bacillus subtilis RSKK96 with solid state fermentation. EurAsian Journal of Biosciences, 72(July), 64-72. https://doi.org/10.5053/ejobios.2011.5.0.8

Aksoy, S. Ç., Uzel, A., \& Hameş Kocabaş, E. E. (2012). Extracellular serine proteases produced by Thermoactinomyces strains from hot springs and soils of West Anatolia. Annals of Microbiology, 62(2), 483-492. https://doi.org/10.1007/s13213-011-0280-z Arslan-Alaton, I., Tureli, G., \& Olmez-Hanci, T. (2009). Treatment of azo dye production wastewaters using Photo-Fenton-like advanced oxidation processes: Optimization by response surface methodology. Journal of Photochemistry and Photobiology A: Chemistry, 202(2-3), 142-153. https://doi.org/10.1016/j.jphotochem.2008.11.019

Bayraktar, E. (2001). Response surface optimization of the separation of dl-tryptophan using an emulsion liquid membrane. Process Biochemistry, 37(2), 169-175. https://doi.org/10.1016/S0032-9592(01)00192-3

Bhunia, B., Basak, B., \& Dey, A. (2012). A review on production of serine alkaline protease by Bacillus spp. Journal of Biochemical Technology, 3(4), 448-457.

Carvalho, C. M. L., Serralheiro, M. L. M., Cabral, J. M. S., \& Aires-Barros, M. R. (1997). Application of factorial design to the study of transesterification reactions using cutinase in AOT-reversed micelles. Enzyme and Microbial Technology, 21(2), 117-123. https://doi.org/10.1016/S0141-0229(96)00245-1

Chang, S.-F., Chang, S.-W., Yen, Y.-H., \& Shieh, C.-J. (2007). Optimum immobilization of Candida rugosa lipase on Celite by RSM. Applied Clay Science, 37(1-2), 67-73. https://doi.org/10.1016/j.clay.2006.12.001

Davati, N., \& Najafi, M. B. H. (2013). Overproduction Strategies for Microbial Secondary Metabolites $\bigotimes$ : a Review Production Over- of Microbial. International Journal of Life Science and Pharma Research, 3, 23-37.

Deepak, V., Kalishwaralal, K., Ramkumarpandian, S., Babu, S. V., Senthilkumar, S. R., \& Sangiliyandi, G. (2008). Optimization of media composition for Nattokinase production by Bacillus subtilis using response surface methodology. Bioresource Technology, 99(17), 8170-4. https://doi.org/10.1016/j.biortech.2008.03.018

El-Enshasy, H. A., Mohamed, N. A., Farid, M. A., \& El-Diwany, A. I. (2008). Improvement of erythromycin production by Saccharopolyspora erythraea in molasses based medium through cultivation medium optimization. Bioresource Technology, 99(10), 4263-8. https://doi.org/10.1016/j.biortech.2007.08.050

Ernst, O., \& Zor, T. (2010). Linearization of the bradford protein assay. Journal of Visualized Experiments区: JoVE, (38). https://doi.org/10.3791/1918

Gokhale, D. V., Patil, S. G., \& Bastawde, K. B. (1991). Optimization of cellulase production by Aspergillus niger NCIM 1207. Applied Biochemistry and Biotechnology, 30(1), 99-109. https://doi.org/10.1007/BF02922026

Hajji, M., Rebai, A., Gharsallah, N., \& Nasri, M. (2008). Optimization of alkaline protease production by Aspergillus clavatus ES1 in Mirabilis jalapa tuber powder using statistical experimental design. Applied Microbiology and Biotechnology, 79(6), 915-23. https://doi.org/10.1007/s00253-008-1508-0

Helal, M., Amer, H., \& Abdelwahed, A. (2012). Physiological and Microbiological
Studies on Production of Alkaline Protease from Locally Isolated Bacillus Subtilis. Australian Journal of Basic and Applied Sciences, 6(3), 193-203.

Hoq, M. M., Mamun, A. Al, Shishir, M. A., Akand, N. R., Khan, M., \& Khan, S. N. (2013). Bioprocess development for eco-friendly microbial products and its impacts on bio-industry establishment in bangladesh. In International Conference on Biotechnology (Vol. 1, pp. 205-217). Dhaka, Bangladesh.: cares.org.bd. Retrieved from http://www.caresbd.org/uploads/book1_14.pdf

Hoq, M. M., Siddiquee, K. A. Z., Kawasaki, H., \& Seki, T. (2005). Keratinolytic Activity of Some Newly Isolated Bacillus Species. Journal of Biological Sciences, 5(2), 193-200. https://doi.org/10.3923/jbs.2005.193.200

Huang, K. xue, Badger, M., Haney, K., \& Evans, S. L. (2007). Large scale production of Bacillus thuringiensis PS149B1 insecticidal proteins Cry34Ab1 and Cry35Ab1 from Pseudomonas fluorescens. Protein Expression and Purification, 53(2), 325-330. https://doi.org/10.1016/j.pep.2007.01.010

Lakshmi, B., \& Hemalatha, K. (2015). Response surface optimization of medium composition for alkaline protease production by Bacillus cereus strain S8. International Journal of Pure and Applied Bioscience, 3(4), 216-223.

Lakshmi, B., \& Hemalatha, K. (2016). Production of Alkaline Protease from Bacillus licheniformis through Statistical Optimization of Growth Media by Response Surface $\begin{array}{llll}\text { Methodology. } & \text { Fermentation }\end{array}$ https://doi.org/10.4172/2167-7972.1000130

Li, J., Ma, C., Ma, Y., Li, Y., Zhou, W., \& Xu, P. (2007). Medium optimization by combination of response surface methodology and desirability function: an application in glutamine production. Applied Microbiology and Biotechnology, 74(3), 563-571. https://doi.org/10.1007/s00253-006-0699-5

Liu, G.-Q., \& Wang, X.-L. (2007). Optimization of critical medium components using response surface methodology for biomass and extracellular polysaccharide production by Agaricus blazei. Applied Microbiology and Biotechnology, 74(1), 78-83. https://doi.org/10.1007/s00253-006-0661-6

Mamun, A. Al, Mian, M., Saifuddin, M., Khan, S. N., \& Hoq, M. (2017). Optimization of fermenting medium by statistical method for production of alkaline protease by Bacillus licheniformis MZK05M9. Journal of Applied Biology \& Biotechnology, 5(6), 24-28. https://doi.org/10.7324/JABB.2017.50604

Md. Mahmuduzzaman Mian. (2014). Optimization of alkaline protease production by Bacillus licheniformis MZK05M9 in batch culture using Response Surface Methodology. Brac University. Brac University. Retrieved from http://hdl. handle.net/10361/4150

Montgomery, D. C. (2006). Design and Analysis of Experiments. Technometrics, 48(1), 158-158. https://doi.org/10.1198/tech.2006.s372

Mourin, M., Shishir, A., Khan, S. N., \& Hoq, M. M. (2015). Regulation of major cultural components for designing a cost effective medium to increase $\delta$-endotoxin synthesis by Bacillus thuringiensis. African Journal of Biotechnology, 14(16), 1379-1386. https://doi.org/10.5897/AJB2014.14340

Nahar, M., Asaduzzaman Shishir, M., Waliullah, S., Sanowarul Haque, M., Ilias, M., Manjurul Karim, M., ... Mozammel Hoq, M. (2016). Cloning, expression and structure simulation of keratinase from Bacillus licheniformis strain MZK05. Malaysian Journal of Microbiology, 12(2), 182-190. https://doi.org/10.21161/mjm.78515

Nazir, Y., Shuib, S., Kalil, M. S., Song, Y., \& Hamid, A. A. (2018). Optimization of Culture Conditions for Enhanced Growth, Lipid and Docosahexaenoic Acid (DHA) Production of Aurantiochytrium SW1 by Response Surface Methodology. Scientific Reports, 8(1), 8909. https://doi.org/10.1038/s41598-018-27309-0 
Qureshi, A. S., Bhutto, M. A., Khushk, I., \& Dahot, M. U. (2011). Optimization of cultural conditions for protease production by Bacillus subtilis EFRL 01. African Journal of Biotechnology, 10(26), 5173-5181. https://doi.org/10.5897/AJB09.1574 Rahman, A., \& Gomes, D. J. (2003). Optimization of medium ingredients for A-mannanase production by Aspergillus sp. isolated from commercial guar gum. Dhaka University Journal of Biological Sciences, 12(2), 153-164.

Rao, K. J., Kim, C.-H., \& Rhee, S.-K. (2000). Statistical optimization of medium for the production of recombinant hirudin from Saccharomyces cerevisiae using response surface methodology. Process Biochemistry, 35(7), 639-647. https://doi.org/10.1016/S0032-9592(99)00129-6

Salaheen, S., Mamun, M. A. Al, Khan, S. N., \& Hoq, M. M. (2015). Improvement of Bacillus licheniformis MZK05 by mutation for increased production of keratinase Dhaka University Journal of Biological Sciences, 24(1), 17-23. Retrieved from http://journal. library.du. ac.bd/index.php?journal=dujbs\&page $=$ article\&op=download \&path\%5B\%5D =1004\&path\%5B\%5D=964 Sarrai, A., Hanini, S., Merzouk, N., Tassalit, D., Szabó, T., Hernádi, K., \& Nagy, L. (2016). Using Central Composite Experimental Design to Optimize the Degradation of Tylosin from Aqueous Solution by Photo-Fenton Reaction. Materials, 9(6), 428-438. https://doi.org/10.3390/ma9060428

Saxena, R., \& Singh, R. (2010). Statistical optimization of conditions for protease production from Bacillus sp. Acta Biologica Szegediensis, 54(2), 135-141.

Sayyad, S. A., Panda, B. P., Javed, S., \& Ali, M. (2007). Optimization of nutrient parameters for lovastatin production by Monascus purpureus MTCC 369 under submerged fermentation using response surface methodology. Applied Microbiology and Biotechnology, 73(5), 1054-8. https://doi.org/10.1007/s00253-006-0577-1

Sen, R. (1997). Response Surface Optimization of the Critical Media Components for the Production of Surfactin. Journal of Chemical Technology \& Biotechnology, 68(3),

$\begin{array}{cccccccc}6 & & 3 & & - & 2 & 7 & 0 \\ \mathrm{~h} & \mathrm{t} & \mathrm{t} & \mathrm{p} & \mathrm{s} & & & \end{array}$
doi.org/10.1002/(SICI)1097-4660(199703)68:3<263::AID-JCTB631>3.0.C0;2-8 Sharma, K. M., Kumar, R., Panwar, S., \& Kumar, A. (2017). Microbial alkaline proteases: Optimization of production parameters and their properties. Journal of Genetic Engineering and Biotechnology, 15(1), 115-126. https://doi.org/https://doi.org/10.1016/j.jgeb.2017.02.001

Song, C., Li, X., Wang, L., \& Shi, W. (2016). Fabrication, Characterization and Response Surface Method (RSM) Optimization for Tetracycline Photodegration by Bi3.84W0.1606.24- graphene oxide (BWO-GO). Scientific Reports, 6(1), 37466. https://doi.org/10.1038/srep37466

Song, Z., Zhao, Z., Qin, X., Huang, J., Shi, H., Wu, B., \& Chen, Q. (2007). Highly sensitive choline biosensor based on carbon nanotube-modified Pt electrode combined with sol-gel immobilization. Frontiers of Chemistry in China, 2(2), 146-150. https://doi.org/10.1007/s11458-007-0030-8

Srinivas, M. R. S., Chand, N., \& Lonsane, B. K. (1994). Use of Plackett-Burman design for rapid screening of several nitrogen sources, growth/product promoters, minerals and enzyme inducers for the production of alpha-galactosidase by Aspergillus niger MRSS 234 in solid state fermentation system. Bioprocess Engineering. https://doi.org/10.1007/BF00369470

Suganthi, C., Mageswari, A., Karthikeyan, S., Anbalagan, M., Sivakumar, A., \& Gothandam, K. M. (2013). Screening and optimization of protease production from a halotolerant Bacillus licheniformis isolated from saltern sediments. Journal of Genetic Engineering and Biotechnology, 11(1), 47-52. https://doi.org/https://doi.org/10.1016/j.jgeb.2013.02.002

Xiao, Z. J., Liu, P. H., Qin, J. Y., \& Xu, P. (2007). Statistical optimization of medium components for enhanced acetoin production from molasses and soybean meal hydrolysate. Applied Microbiology and Biotechnology, 74(1), 61-8. https://doi.org/10.1007/s00253-006-0646-5
Submit your next manuscript to Microbial Bioactives published by EMAN Research

- Convenient online submission

- Thorough peer review

- No space constraints or color figure charges

- Immediate publication on acceptance

- Inclusion in Australian National Libraray and Google Scholar

- Both Open (80-100\% subsidized APC by ER) \& non-open access option 